\title{
Assessment of the Potential of Lactic Acid Bacteria as Dried Starter Culture for Cereal Fermentation
}

\author{
Amenan A. Soro-Yao ${ }^{1 *}$, Solange Aka ${ }^{1}$, Philippe Thonart ${ }^{2,3}$ and Koffi M. Djè ${ }^{1}$ \\ ${ }^{1}$ Science and Food Technology Unit, University Nangui Abrogoua 02 BP 801 Abidjan 02, Côte d'Ivoire. \\ ${ }^{2}$ Wallon Center for Industrial Microbiology (CWBI), University of Liège, Bld du Rectorat 29-B40, B4000 Liège, \\ Belgium \\ ${ }^{3}$ Walloon Center of Industrial Biology, Bio-industry unit, Gembloux Agro-Bio Tech, 5030 Gembloux, Belgium
}

\begin{abstract}
The kinetic growth parameters [maximal specific growth rate $\mu_{m}\left(\mathrm{~h}^{-1}\right)$, and generation time $g(\mathrm{~h})$ ] and viability after stress treatments (dehydration with glycerol solution of increasing concentration, freezing or heating stress) of four lactic acid bacteria [Lactobacillus plantarum (LP), L. fermentum (LF), Leuconostoc spp. (M1) and Lactococcus spp. (M2)] were determined. The maximal specific growth rate $\left(\mu_{m}\right)$ and generation time $g$ ranged between $0.51 \mathrm{~h}^{-1}$ to $0.14 \mathrm{~h}^{-1}$ and $0.61 \mathrm{~h}$ to $1.33 \mathrm{~h}$, respectively. We observed that the strains were sensitive to a change in water activity ( $\mathrm{a}_{\mathrm{w}} 0.32$ final), storage and incubation temperatures. The Strain LF obtained a higher cell concentration and viability, as well as a lower $g$ compared to those obtained by the other strains. The kinetic growth parameters $\left(\mu_{\mathrm{m}}, \mathrm{g}\right)$ together with viability after stress treatments could be used for the screening of dried lactic acid starter cultures.
\end{abstract}

Keywords: Dehydration tolerance, generation time, lactic acid bacteria, starter cultures, stress treatment, viability, water activity.

\section{INTRODUCTION}

Traditional fermented cereal based foods consumed in Africa are processed by natural fermentation of maize, sorghum and/or millet and are particularly important as weaning foods for infants and dietary staples for adults $[1,2]$. The use of dried lactic acid bacteria (LAB) starter cultures during fermented cereal based foods processing could result in a high degree of control over the fermentation process and standardization of the end product. We need to take into account technological effectiveness when selecting strains for food fermentation. Commercial starter cultures are supplied in concentrated form by freeze-drying, vacuumdrying, spray-drying, drum-drying, fluidized bed drying or air-drying. These techniques impose environmental stress on the bacterial cells, such as freezing, drying, long-term exposure to low water activities and re-hydration. Moreover, during cereal fermentation processes, LAB are exposed to various environmental stress conditions, such as temperature fluctuations, acid, $\mathrm{pH}$, high osmotic pressure and absence of available nutrients.

The suitability of LAB starter cultures for large-scale production and their stability during drying and storage in the dried state are important criteria for dried starter culture selection. The evaluation of cell viability under different

*Address correspondence to this author at the Science and Food Technology Unit, University Nangui Abrogoua 02 BP 801 Abidjan 02, Côte d'Ivoire; Tel: +225 45008631; Fax: +225 31202034; Email: amenansoro@yahoo.fr stress conditions could be a valuable tool to evaluate the potential of lactic acid bacteria to be produced in the dried state [3]. The ability of LAB to establish them-selves and to dominate the LAB population during cereal dough fermentation is another important characteristic of a starter culture. The dominance of the starter culture would be exerted by its fast and predominant growth under fermentation conditions. In predictive food microbiology, the generation time $(g)$ is often used to characterize bacterial growth curve [4]. The generation time is the time needed for doubling the initial population during the exponential growth phase. It is directly linked to the maximal specific growth rate $\left(\mu_{m}\right)$, which is the slope of the logarithm of the growth curve in the exponential growth phase.

The objective of the present study was to determine the kinetic growth parameters $\left(\mu_{m}, g\right)$ and viability under stress treatments in order to assess the ability to tolerate dehydration of LAB isolated from fermented cereal foods in Côte d'Ivoire.

\section{MATERIAL AND METHODS}

\section{Microorganisms and Preparation of the Seed Bank}

The strains Lactobacillus plantarum (LP), L. fermentum (LF), Leuconostoc spp (M1) and Lactococcus spp (M2), belonging to the collection of lactic acid bacteria of our University, were used. The strains had previously been isolated from cereal based fermented foods. Each strain was inoculated in MRS broth and incubated at $30^{\circ} \mathrm{C}$ for $18 \mathrm{~h}$. The 
cells obtained after concentration $(2500 \times \mathrm{g}, 20 \mathrm{~min})$ were maintained in $50 \%(\mathrm{v} / \mathrm{v})$ glycerol and frozen at $-80^{\circ} \mathrm{C}$ (stock culture). Fifty $\mu 1$ of the stock cultures were used to inoculate $150 \mathrm{ml}$ of MRS broth, which was incubated at $30 \pm 2^{\circ} \mathrm{C}$ for $22 \mathrm{~h}$. Ten ml aliquots of the culture broths were withdrawn at $2 \mathrm{~h}$ intervals during incubation, and used for growth determinations.

\section{Analytical Methods}

Viable counts were carried out on MRS agar medium with incubation at $30^{\circ} \mathrm{C}$ for $48 \mathrm{~h}$. Dry weight (DW) was obtained after drying at $105^{\circ} \mathrm{C}$ until constant weight was achieved. Viable counts were expressed on dry weight basis. The $\mathrm{pH}$ of the fermentation broths was determined using a pH-meter. The maximal specific growth rate $\left(\mu_{m}\right)$ and the generation time $(g)$ were obtained by directly fitting the logarithmic transformation of plate counts versus time:

$g=\frac{0.693}{\mu m}$

$\mu_{m}=\frac{\operatorname{Ln~} \mathrm{N}_{1}-\mathrm{Ln} \mathrm{N}_{0}}{\mathrm{t}_{1}-\mathrm{t}_{0}}$

Where $g(\mathrm{~h})$ is the generation time, $\mathrm{N}_{0}$ the initial population at time $\mathrm{t}_{0}(\mathrm{cfu} / \mathrm{g} \mathrm{DW}), \mathrm{N}_{\mathrm{t}}$ is the population at time $\mathrm{t}(\mathrm{cfu} / \mathrm{g}$ $\mathrm{DW})$, and $\mu_{m}\left(\mathrm{~h}^{-1}\right)$ is the maximal specific growth rate.

\section{Assessment of Ability to Tolerate Dehydration}

\section{Effect of Dehydration with Glycerol Solution on Viability of Tested Bacteria}

About fifty $\mu \mathrm{l}$ of each stock culture was inoculated in 150 $\mathrm{ml}$ MRS broth and incubated at $30^{\circ} \mathrm{C}$ for $18 \mathrm{~h}$. The cell pellets obtained after concentration $(2500 \times \mathrm{g}, 20 \mathrm{~min})$ were re-suspended in $1 \mathrm{ml} 0.5 \%$ peptone salt solution. One $\mathrm{ml}$ of $90 \%(\mathrm{w} / \mathrm{w})$ glycerol was added to the cell suspension, homogenized and allowed to stand for $15 \mathrm{~min}$ at room temperature. The same procedure was repeated four times, and the cell suspension obtained was concentrated by centrifugation $(2500 \times \mathrm{g}, 3 \mathrm{~min})$ followed by two washing steps with $0.5 \%$ peptone salt solution. After concentration at $2500 \times \mathrm{g}$ for $30 \mathrm{~s}$, cell suspensions were re-suspended in 100 $\mathrm{ml}$ of $0.5 \%$ peptone salt solution for viable counts and dry weight determinations. Cell suspension without glycerol was used as the control. The water activity $\left(\mathrm{a}_{\mathrm{w}}\right)$ was estimated after each addition of glycerol with Norrish equation:

$\mathrm{a}_{\mathrm{w}}=(1-\mathrm{X}) e^{-K X^{2}}$

where $\mathrm{a}_{\mathrm{w}}$ is water activity, $\mathrm{X}$ is the molar fraction glycerol, and $\mathrm{K}=1.16$ is the correlating constant for glycerol at $25^{\circ} \mathrm{C}$.

\section{Effect of Freezing on Viability of Tested Bacteria}

Three $\mathrm{ml}$ aliquots of $18 \mathrm{~h}$ culture of each stock culture in $150 \mathrm{ml}$ MRS broth were distributed into $15 \mathrm{ml}$ Falcon ${ }^{\circledR}$ tubes, frozen and stored at $-80{ }^{\circ} \mathrm{C}$ for $4 \mathrm{~h}$. The tubes were then defrosted in a water bath at $50^{\circ} \mathrm{C}$ for $10 \mathrm{~min}$ and cooled at room temperature $\left(30^{\circ} \pm 2^{\circ} \mathrm{C}\right)$ for $20 \mathrm{~min}$.

\section{Effect of Incubation Temperature on Viability of Tested Bacteria}

Three $\mathrm{ml}$ aliquots of $18 \mathrm{~h}$ culture of each stock culture in $150 \mathrm{ml}$ MRS broth were distributed into $15 \mathrm{ml} \mathrm{Falcon}{ }^{\circledR}$ tubes, frozen and stored at $-80{ }^{\circ} \mathrm{C}$ for $4 \mathrm{~h}$. The tubes were then defrosted in a water bath at $50^{\circ} \mathrm{C}$ for $10 \mathrm{~min}$ and cooled at room temperature $\left(30^{\circ} \pm 2^{\circ} \mathrm{C}\right)$ for $20 \mathrm{~min}$.

\section{Data Analyses}

All inoculations and essays were carried out in duplicate and the average values were recorded. Viable counts and dry weight were determined after each stress treatment, and compared to those of the control (cell without treatment). Viable counts were expressed dry weight basis. The percentage survival of the strains before and after stress treatments was expressed as follows: Survival $(\%)=\mathrm{N}_{0} / \mathrm{N}_{\mathrm{c}}$ $\times 100$, where $\mathrm{N}_{0}$ is the cfu/g DW before stress treatment and $\mathrm{N}_{\mathrm{c}}$ is the cfu/g DW after stress treatment. Data were compared using Tukey's honestly significant difference and Student $t$ test (Statistica 8.0, StatSoft Inc., 2007). The level of significance was set at $\mathrm{P}=0.05$.

\section{RESULTS AND DISCUSSION}

The selection of LAB as dried starter culture for cereal fermentation is a complex process, involving the evaluation of some desired metabolic traits and technological performances. Although the selection needs to take into account many parameters (acidification, production of antimicrobial compounds, viability after dehydration, etc.), this work proposes a first approach based upon kinetics growth parameters and the ability to overcome stressful conditions. Modeling of cell growth, acidification power as well as production of bacteriocins and exopolysaccharides could be used to predict LAB starter cultures bio-kinetics in food industry [5]. Primary growth models such as the maximal specific growth rate $\left(\mu_{\mathrm{m}}\right)$ and the generation time (g) could be used to describe changes in microbial numbers (viability) or microbial responses with time [4]. The linear part of the growth logarithmic plot characterized the exponential growth (Fig. 1). The slope of the straight line corresponded to $\mu_{\mathrm{m}}$ (Equation 2, Table 1). This graph clearly shows that exponential growth followed immediately the adaptation phase of the inoculated biomass to the physicochemical conditions and medium, since growth became exponential after less than $3 \mathrm{~h}$. The generation time $(g)$ is the time needed for doubling the initial bacterial population during the exponential growth. It is directly linked to the specific growth rate (Equation 1, Table 1). The generation time values, which ranged from 0.61 to $1.33 \mathrm{~h}$, were compared to those (ranging from 0.5 to $2.3 \mathrm{~h}$ ) of Beal et al. [6] reported for lactic acid bacteria on MRS medium. The maximal specific growth rate $\left(1.14 \mathrm{~h}^{-1}\right)$ and $g(0.61 \mathrm{~h})$ were, significantly higher and lower for the strain $L$. fermentum (LF) compared with those obtained by the strains LP, M1 and M2, respectively. 


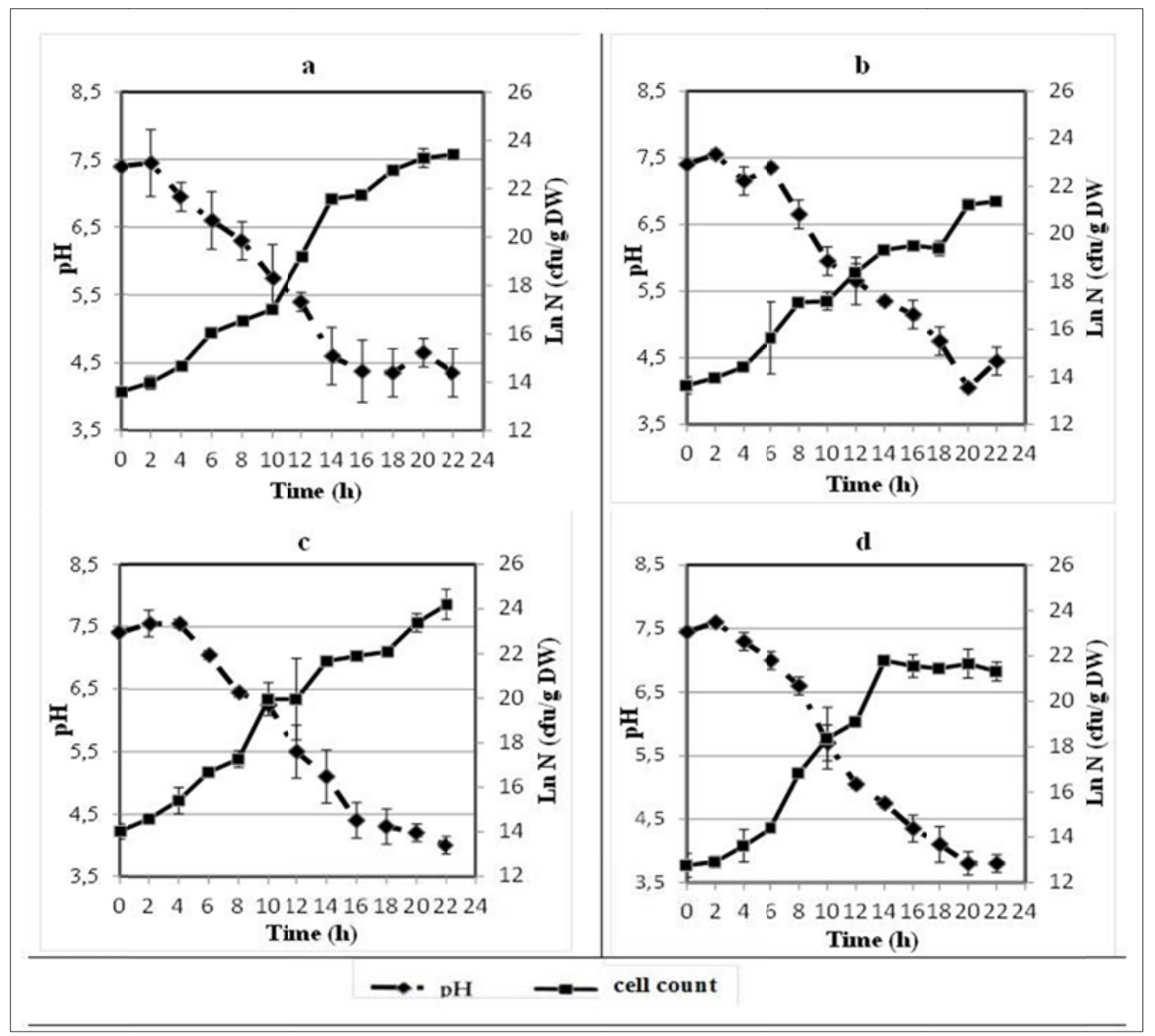

Fig (1). Viable cell counts (₫) and pH values ( $\bullet$ during fermentation with (a) Lactobacillus fermentum (LF), (b) L. plantarum (LP), (c) Lactococcus spp M1 (d) Leuconostoc spp M2. Values are presented as means \pm Standard Deviation (SD) $(\mathrm{n}=4)$.

Table 1. Growth and kinetic growth parameters after 18h culture of Lactobacillus fermentum (LF), L. plantarum (LP), Lactococcus spp M1, Leuconostoc spp M2 on MRS medium.

\begin{tabular}{ccccc}
\hline Strains & \multicolumn{2}{c}{ Growth parameters } & \multicolumn{2}{c}{ Kinetic growth parameters } \\
\hline & Viable counts $(\mathrm{cfu} / \mathrm{ml})$ & Dry weight $(\%)$ & $\mu_{m}\left(\mathrm{~h}^{-1}\right)$ & $g(\mathrm{~h})$ \\
\hline LF & $2.63 \times 10^{8} \pm 6.01 \times 10^{7 \mathrm{a}}$ & $3.39 \pm 0.07^{\mathrm{a}}$ & $1.14 \pm 0.03^{\mathrm{a}}$ & $0.61 \pm 0.02^{\mathrm{a}}$ \\
LP & $9.15 \times 10^{6} \pm 2.62 \times 10^{5 \mathrm{~b}}$ & $3.39 \pm 0.17^{\mathrm{a}}$ & $0.54 \pm 0.08^{\mathrm{b}}$ & $1.33 \pm 0.05^{\mathrm{b}}$ \\
M1 & $1.36 \times 10^{8} \pm 8.84 \times 10^{6 \mathrm{c}}$ & $3.49 \pm 0.05^{\mathrm{a}}$ & $1.05 \pm 0.05^{\mathrm{ab}}$ & $0.73 \pm 0.08^{\mathrm{ab}}$ \\
M2 & $7.10 \times 10^{7} \pm 8.70 \times 10^{6 \mathrm{bc}}$ & $3.40 \pm 0.13^{\mathrm{a}}$ & $0.57 \pm 0.03^{\mathrm{b}}$ & $1.22 \pm 0.06^{\mathrm{b}}$ \\
\hline
\end{tabular}

cfu: Colony-forming units

$\mu_{\mathrm{m}}$ : Maximal specific growth rate

$g$ : Generation time

Values are presented as means $\pm \operatorname{SD}(n=4)$

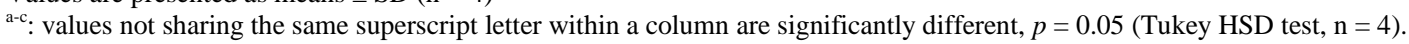


The ability of the 4 strains to overcome stressful conditions was assessed by viable counts after dehydration in a glycerol solution of increasing concentration (from 1 to 5 $\mathrm{ml}$ ), heat and freezing stresses. An increase in glycerol concentration was associated with a decrease in water activity $\left(a_{w}\right)$ from 0.8 to 0.3 (Equation 3 , Table 2 ). The impact of the decrease in $a_{w}$ on the viability of the strains was studied after viable counts and was compared with that of the control (cells without dehydration). The change in $a_{w}$ in the environment of the bacteria had a significant effect on their viability, and this varied from one strain to another. All the strains did not recover more than $50 \%$ of their population value, whereas the strain L. fermentum (L) showed a higher viability than the others strains. In an earlier study, most of lactic acid bacteria strains (12 out of 16) recovered more than $50 \%$ of their population value after dehydration in a glycerol solution with a final $\mathrm{a}_{\mathrm{w}}$ of about 0.3 [3]. The results obtained and reported here are only approximate, since the final $\mathrm{a}_{\mathrm{w}}$ of the water glycerol solution in our study (0.3) was higher than that obtained generally for freeze-dried lactic acid powders (0.1-0.2) [7]. Freezing had a significant effect on bacterial viability, and this varied from one strain to another, as shown in Table $\mathbf{3}$. Significant loss in viability of Lactobacillus delbrueckii ssp. bulgaricus CFL1 after freeze thawing in MRS broth was reported [8]. This difference in cell viability between strains was linked to the intrinsic resistance of the strain, the initial concentration, growth conditions and possibly the elimination of a large part of the sensitive population during the freezing step [9]. The strains were sensitive to a variation in the incubation temperature as shown in Table 4. This sensitivity to change in the incubation temperature was characterized by a loss of viability between $98 \%$ and $100 \%$ or about $100 \%$ at $54^{\circ} \mathrm{C}$ or $75^{\circ} \mathrm{C}$, respectively. Significant effect of temperature on the viability of LAB used as starter cultures has already been reported [10, 11]. However, the effect of incubation temperature was less evident in our study. The elimination of the most sensitive part of cell population during the stress treatment could be suggested.

These results indicate that the kinetic growth parameters $\left(\mu_{\mathrm{m}}, g\right)$ together with the viability after stress treatments could be used to predict the potential of LAB as dried starter culture. However, further attempts for the screening of LAB dried starter culture must be made.

\section{CONFLICT OF INTEREST}

The authors confirm that this article content has no conflicts of interest.

\section{ACKNOWLEDGMENTS}

We thank the International Foundation for Science (IFS, grant $\mathrm{n}^{\circ}$ E/4953-1) and The World Academy of Sciences (TWAS, grant FR: 3240262723) for the providing the funds. We would also like to extend our gratitude to Dr. Boreaud M., Dr. N' Guessan F. for their helpful comments on the results and Dr. Karamoko D. for his help during data collection.

Table 2. Viable count and survival of strains after dehydration with a glycerol solution of increasing concentration.

\begin{tabular}{|c|c|c|c|}
\hline \multirow[t]{2}{*}{ Strains } & \multicolumn{2}{|c|}{ Viable count (cfu/g DW) } & Survival (\%) \\
\hline & Before treatment $\left(a_{w}=1\right)$ & After treatment $\left(a_{w}=0.32\right)$ & \\
\hline LF & $2.06 \times 10^{12} \pm 2.24 \times 10^{11}$ & $4.43 \times 10^{11} \pm 4.48 \times 10^{10}$ & $20.95 \pm 3.07^{\mathrm{a}}$ \\
\hline LP & $1.44 \times 10^{12} \pm 1.86 \times 10^{11}$ & $2.49 \times 10^{11} \pm 6.81 \times 10^{10}$ & $17.42 \pm 4.30^{b}$ \\
\hline M1 & $3.08 \times 10^{12} \pm 8.41 \times 10^{11}$ & $3.73 \times 10^{11} \pm 6.88 \times 10^{10}$ & $12.57 \pm 3.40^{\mathrm{c}}$ \\
\hline M2 & $2.14 \times 10^{12} \pm 4.47 \times 10^{11}$ & $3.41 \times 10^{11} \pm 7.45 \times 10^{10}$ & $16.26 \pm 4.03^{b}$ \\
\hline
\end{tabular}

cfu: Colony-forming units

Values are presented as means $\pm \operatorname{SD}(n=4)$.

${ }^{\mathrm{a}-\mathrm{c}}$ : values not sharing the same superscript letter within a column are significantly different, $p=0.05$ (Tukey HSD test, $\mathrm{n}=4$ ).

* Molar fraction of glycerol ( $5 \mathrm{ml}$ glycerol $+1 \mathrm{ml}$ culture media) is 0.55

Table 3. Viable count and survival of strains after freezing stress.

\begin{tabular}{lccc}
\hline Strains & \multicolumn{2}{c}{ Viable count $(\mathrm{cfu} / \mathrm{g} \mathrm{DW})$} & Survival (\%) \\
\hline BF & $3.11 \times 10^{11} \pm 3.56 \times 10^{10}$ & $9.60 \times 10^{10} \pm 1.99 \times 10^{9}$ & $31.03 \pm 6.02^{\mathrm{a}}$ \\
LP & $1.03 \times 10^{12} \pm 1.06 \times 10^{11}$ & $8.72 \times 10^{10} \pm 1.35 \times 10^{9}$ & $8.51 \pm 1.30^{\mathrm{bc}}$ \\
M1 & $3.21 \times 10^{11} \pm 7.63 \times 10^{10}$ & $3.73 \times 10^{9} \pm 9.60 \times 10^{8}$ & $1.20 \pm 0.11^{\mathrm{b}}$ \\
M2 & $4.86 \times 10^{11} \pm 1.19 \times 10^{10}$ & $7.73 \times 10^{10} \pm 1.57 \times 10^{9}$ & $16.38 \pm 4.26^{\mathrm{c}}$ \\
\hline
\end{tabular}

cfu: Colony-forming units

Values are presented as means \pm SD $(n=4)$

${ }^{\mathrm{a}-\mathrm{c}}$ : values not sharing the same superscript letter within a column are significantly different, $p=0.05$ (Tukey HSD test, $\mathrm{n}=4$ ). 
Table 4. Viable count and survival of strains after incubation at à $54^{\circ} \mathrm{C}$ or $75^{\circ} \mathrm{C}$.

\begin{tabular}{|c|c|c|c|c|c|}
\hline \multirow[t]{3}{*}{ Strains } & \multicolumn{3}{|c|}{ Viable count (cfu/g DW) } & \multicolumn{2}{|c|}{ Survival (\%) } \\
\hline & \multirow[t]{2}{*}{ Before treatment } & \multicolumn{2}{|c|}{ After treatment } & & \\
\hline & & $\mathrm{T}=45^{\circ} \mathrm{C}$ & $\mathrm{T}=75^{\circ} \mathrm{C}$ & $\mathrm{T}=45^{\circ} \mathrm{C}$ & $\mathrm{T}=75^{\circ} \mathrm{C}$ \\
\hline$\overline{\mathrm{LF}}$ & $7.42 \times 10^{11} \pm 1.30 \times 10^{10}$ & $3.08 \times 10^{9} \pm 1.45 \times 10^{8}$ & $2.87 \times 10^{8} \pm 6.93 \times 10^{7}$ & $0.42 \pm 0.17 *^{\mathrm{a}}$ & $0.04 \pm 0.01 *^{* \mathrm{a}}$ \\
\hline LP & $5.18 \times 10^{11} \pm 9.99 \times 10^{9}$ & $4.74 \times 10^{9} \pm 1.56 \times 10^{8}$ & $3.11 \times 10^{8} \pm 1.08 \times 10^{7}$ & $0.92 \pm 0.15^{* b}$ & $0.06 \pm 0.02 * *^{\mathrm{a}}$ \\
\hline M1 & $4.61 \times 10^{11} \pm 9.70 \times 10^{10}$ & $7.72 \times 10^{9} \pm 1.63 \times 10^{8}$ & $6.37 \times 10^{8} \pm 5.82 \times 10^{7}$ & $1.71 \pm 0.30^{* \mathrm{c}}$ & $0.14 \pm 0.03 * * \mathrm{~b}$ \\
\hline M2 & $4.37 \times 10^{11} \pm 2.20 \times 10^{8}$ & $3.05 \times 10^{9} \pm 2.89 \times 10^{6}$ & $5.58 \times 10^{8} \pm 5.04 \times 10^{7}$ & $0.70 \pm 0.05^{* a b}$ & $0.13 \pm 0.09 * * b$ \\
\hline
\end{tabular}

T: Temperature $\left({ }^{\circ} \mathrm{C}\right)$

cfu: Colony-forming units

Values are presented as means \pm SD $(n=4)$

${ }^{\mathrm{a}-\mathrm{c}}$ : Values not sharing the same letter within a column are significantly different, $p=0.05$ (Tukey HSD test, $\mathrm{n}=4$ ).

*Values sharing different superscript marks within a raw are significantly different $p=0.05$ (Student $t$ test, $\mathrm{n}=4$ ).

\section{REFERENCES}

[1] Owusu-Kwarteng J, Akabanda F, Nielsen DS, et al. Identification of lactic acid bacteria isolated during traditional fura processing in Ghana. Food Microbiol 2012; 32: 72-8.

[2] Soro-Yao AA, Brou K, Koffi-Nevry R, Djè KM. Microbiology of Ivorian fermented products: A review. Asian J Agric Food Sci 2013; 1: 37- 47.

[3] Yao AA, Dortu C, Egounlety M, et al. Production of freeze-dried lactic acid bacteria starter culture for cassava fermentation into gari. Afr J Biotechnol 2009; 8: 4996-5004.

[4] Delignette-Muller ML. Relation between the generation time and the lag time of bacterial growth kinetics. Int J Food Microbiol 1998; 43: 97-104.

[5] Leroy F, Degeest B, De Vuyst L. A novel area of predictive modelling: describing the functionality of beneficial microorganisms in foods. Int J Food Microbiol 2002; 73: 251-9.

[6] Beal CD, Juillard V, De Roissart H, et al. In : De Roissart H, Luquet FM, Eds. Cinétique de croissance et d'acidification des bactéries lactiques. Les bactéries lactiques: Aspects fondamentaux, Lorica, Uriage 1994; pp. 367-399.

[7] Cheftel JC, Cheftel H, Besançon P. Introduction à la biochimie et à la technologie des aliments, Lavoisier Publishers, Paris, France, 1992; p. 382.

[8] Gautier J, Passot S, Pénicaud C, et al. A low membrane lipid phase transition temperature is associated with a high cryotolerance of Lactobacillus delbrueckii subspecies bulgaricus CFL1. J Dairy Sci 2013; 96: 5591-602.

[9] Beal C, Fonseca F, Corrieu G. Resistance to freezing and frozen storage of Streptoccocus thermophilus is related to membrane fatty acid composition. J Dairy Sci 2001; 84: 2347-2356.

[10] Zotta T, Guidone A, Ianniello RG, et al. Temperature and respiration affect the growth and stress resistance of Lactobacillus plantarum C17. J Appl Microbiol 2013; 115: 848-58.

[11] Zotta T, Guidone A, Tremonte P, et al. A comparison of fluorescent stains for the assessment of viability and metabolic activity of lactic acid bacteria. World J Microbiol Biotechnol 2012; 28: 919-27.

(C) Soro-Yao et al.; Licensee Bentham Open.

This is an open access article licensed under the terms of the Creative Commons Attribution Non-Commercial License (http://creativecommons.org/licenses/ by-nc/3.0/) which permits unrestricted, non-commercial use, distribution and reproduction in any medium, provided the work is properly cited. 